\title{
PERBEDAAN TINGKAT KONSUMSI DAN KADAR KOLESTEROL DARAH ANTARA PEROKOK DAN NON PEROKOK
}

\section{THE DIFFERENCE IN CONSUMPTION LEVELS AND BLOOD CHOLESTEROL LEVELS BETWEEN SMOKERS AND NON-SMOKERS}

\author{
Dina Fahmawati \\ Departemen Gizi Kesehatan, \\ Fakultas Kesehatan Masyarakat, Universitas Airlangga, Surabaya, Indonesia \\ Alamat Korespondensi:Dina Fahmawati \\ Email:dinafa7@gmail.com
}

\begin{abstract}
Cigarette smoke contains nicotine which disturbs health. Nicotine is capable of reducing the taste of food, so there is appetite suppressant. The ability of nicotine in increasing blood liposuction process can affect the increase in blood cholesterol level. The research aims to study the difference between food intake and blood cholesterol level between smokers and non-smokers. This study was a comparative observational analytic study using cross-sectional design. The data of particular subjects and smoking habit were obtained from the questionnaire. The food intake was obtained by interview using $2 \times 24$ hours food recall form while the blood cholesterol level was obtained by blood sampling which was then analyzed using laboratory test. The subjects were 13 smokers and 13 non-smokers, taken by simple random sampling. The data were analyzed by Independent t-Test. The results have suggested that the difference in the average food intake and blood cholesterol level between smokers and non-smokers were not significant. The substantial average difference was found in the level of cholesterol intake, so the statistical test has showed a significant difference, $p$-value = $0.005<\alpha(0.05)$. Smoking has a harmful effect for health so people must decrease its consumption or stay abstinent from it. The longer human get exposed to cigarette, the more susceptible they get the illness from it.
\end{abstract}

Keywords: cigarette, blood cholesterol level, food intake

\begin{abstract}
ABSTRAK
Asap rokok mengandung nikotin yang mengganggu kesehatan. Nikotin dapat mengurangi cita rasa makanan sehingga terjadi penekanan selera makan. Kemampuan nikotin dalam meningkatkan proses pelarutan lemak darah dapat mempengaruhi peningkatan kadar kolesterol darah. Penelitian ini bertujuan untuk mempelajari perbedaan tingkat konsumsi dan kadar kolesterol darah antara perokok dan non perokok. Penelitian ini merupakan penelitian observasional analitik dan bersifat komparatif dengan rancangan cross sectional. Karakteristik responden dan kebiasaan merokok diperoleh dari kuesioner. Tingkat konsumsi diperoleh dengan metode wawancara food recall 2x24 jam dan kadar kolesterol darah diperoleh melalui pengambilan sampel darah menggunakan alat uji laboratorium. Besar sampel sebanyak 13 perokok dan 13 non perokok dipilih dengan simple random sampling. Analisis data menggunakan uji Independent $t$-Test. Hasil penelitian menunjukkan bahwa rata-rata konsumsi zat gizi dan kadar kolesterol darah antara responden perokok dan responden non perokok tidak berbeda jauh. Selisih rata-rata terbesar ditemukan pada tingkat konsumsi kolesterol sehingga secara uji statistik memiliki perbedaan yang signifikan, $p=0,005<\alpha(0,05)$. Merokok memberikan dampak buruk bagi kesehatan sehingga diperlukan untuk mengurangi jumlah rokok yang dihisap atau bahkan menghindari merokok. Semakin lama terkena paparan rokok maka lebih mudah terkena penyakit akibat paparan rokok.
\end{abstract}

Kata kunci: rokok, kadar kolesterol darah, tingkat konsumsi.

\section{PENDAHULUAN}

Menurut data World Health Organization - Framework Convention on Tobacco Control (WHO - FCTC) tahun 2015, Indonesia menempati peringkat ketiga teratas berdasarkan distribusi perokok laki-laki berusia 15 tahun ke atas.
Sebanyak 50,6 juta penduduk Indonesia tercatat sebagai perokok. Jumlah perokok yang sangat banyak tidak hanya ditemukan di negara berkembang tetapi juga di negara maju. Sebanyak 21,6 juta penduduk Amerika tercatat sebagai perokok dan menempati peringkat keenam teratas dunia. 
Perokok aktif di Indonesia cenderung meningkat baik pada laki-laki maupun perempuan berdasarkan data Riset Kesehatan Dasar tahun 2010 dan 2013. Perokok aktif (laki-laki dan perempuan) usia di atas 15 tahun adalah $34,7 \%$ pada tahun 2010 dan 35,1\% pada tahun 2013. Peningkatan lebih banyak pada perempuan dari $4,2 \%$ pada tahun 2010 menjadi $6,7 \%$ pada tahun 2013, sedangkan pada laki-laki dari $65,9 \%$ pada tahun 2010 menjadi $66 \%$ pada tahun 2013. Hal ini menunjukkan bahwa merokok telah menjadi gaya hidup buruk yang susah dihilangkan (Balitbangkes RI, 2010 dan 2013). Saat ini masalah kesehatan bergeser dari penyakit infeksi ke penyakit degeneratif. Perubahanan gaya hidup, pola makan, kurangnya aktivitas fisik, faktor stres dan lingkungan diduga merupakan menjadi penyebabnya. Merokok merupakan gaya hidup yang buruk (Departemen Kesehatan RI, 2007).

Zat berbahaya utama pada rokok adalah nikotin, tar dan karbon monoksida (Larson, 2003). Reaksi nikotin dalam tubuh terjadi sangat cepat dimulai masuk ke mulut kemudian larut dalam air ludah. Nikotin yang larut dalam air ludah masuk ke pembuluh darah dan terbawa hingga ke otak sehingga mempengaruhi berbagai proses dalam tubuh (Healey, 2011). Efek nikotin pada perokok salah satunya adalah dapat mempengaruhi selera makan. Perokok cenderung mengurangi porsi makannya karena nikotin menyebabkan penekanan selera makan. Merokok cenderung mengurangi cita rasa pada makanan bagi perokok sehingga perokok lebih memilih merokok daripada mengkonsumsi makanan (Ilfandari, 2015). Seorang perokok lebih berisiko untuk berperilaku makan tidak sehat dibandingkan bukan perokok. Hal ini dibuktikan dengan hasil penelitian yang menyatakan bahwa perokok secara signifikan lebih mungkin untuk terlibat dalam pembatasan diet yang tidak sehat daripada non perokok (Cavallo et al dalam Aginta, 2011).
Merokok dapat penyebab timbulnya radikal bebas dalam tubuh. Radikal bebas tersebut akan merusak berbagai komponen biologis dalam tubuh termasuk LDL kolesterol. Rokok dapat merendahkan kadar kolesterol HDL sekitar 4,5 - 6\% akibatnya kadar kolesterol LDL semakin tinggi dan hal ini memberikan pengaruh pada kadar kolesterol total yang relatif semakin tinggi pula (Listiana, 2010).

Berdasarkan penelitian Kusumasari (2015) pada pegawai salah satu pabrik gula menunjukkan bahwa responden yang merokok dan mempunyai kadar kolesterol tinggi sebanyak 26 responden sedangkan responden yang merokok dan mempunyai kadar kolesterol normal sebanyak 4 responden. Dari kelompok kontrol didapatkan responden yang tidak merokok dan mempunyai kadar kolesterol normal sebanyak 27 responden sedangkan responden yang tidak merokok dan mempunyai kadar kolesterol tinggi sebanyak 3 responden. Rata-rata kadar kolesterol total responden yang merokok adalah $250,5 \mathrm{mg} / \mathrm{dL}$, sedangkan rata-rata kadar kolesterol responden yang tidak merokok adalah 166,2 mg/dL. Didapatkan perbedaan kadar kolesterol total yang signifikan antara responden yang merokok dan responden yang tidak merokok. Hasil penelitian tersebut menunjukkan bahwa kadar kolesterol lebih tinggi pada perokok dibandingkan dengan non perokok.

Berdasarkan uraian di atas, penelitian ini bertujuan mempelajari perbedaan tingkat konsumsi dan kadar kolesterol darah antara perokok dan non perokok. Penelitian ini dilakukan pada pegawai laki-laki perokok dan non perokok Fakultas Kesehatan Masyarakat Universitas Airlangga Surabaya. Yang disebut pegawai dalam penelitian ini adalah mereka yang tercatat sebagai tenaga kerja di lingkungan Fakultas Kesehatan Masyarakat non dosen.

\section{METODE PENELITIAN}

$\begin{array}{ccr}\text { Penelitian ini } & \text { merupakan } \\ \text { observasional analitik dan bersifat }\end{array}$


komparatif dengan rancangan cross sectional. Variabel dalam penelitian ini meliputi tingkat konsumsi zat gizi (energi, karbohidrat, protein, lemak, kolesterol dan serat), kadar kolesterol darah dan kebiasaan merokok. Lokasi penelitian ini adalah di Fakultas Kesehatan Masyarakat Universitas Airlangga Surabaya. Waktu penelitian dilakukan pada bulan Januari 2017. Subjek yang diteliti dalam penelitian ini adalah pegawai laki-laki perokok dan bukan perokok yang berjumlah masingmasing sebanyak 13 orang. Responden perokok merupakan seorang perokok aktif yang dikategorikan berdasarkan Indeks Brinkman. Indeks Brinkman merupakan perkalian antara jumlah rata-rata batang rokok yang dihisap sehari dan lama merokok dalam tahun. Hasil tersebut kemudian dikategorikan menjadi perokok berat, sedang dan ringan (Wikibuku, 2015).

Data konsumsi makanan diperoleh melalui wawancara menggunakan kuesioner penilaian konsumsi pangan food recall 2x24 jam yang meliputi jenis dan jumlah makanan yang dikonsumsi. Tingkat kecukupan zat gizi diperoleh dengan cara membandingkan jumlah konsumsi zat gizi dengan Angka Kecukupan Gizi (AKG). Pengukuran kadar kolesterol darah menggunakan sampel darah yang diambil pada pembuluh darah vena oleh tenaga medis kemudian diperiksa di Laboratorium Gizi Fakultas Kesehatan Masyarakat Universitas Airlangga Surabaya dengan satu kali pemeriksaan. Sebelumnya responden berpuasa selama 8 jam. Data dianalisis dengan menggunakan uji Independent $t$-Test $(\alpha=0,05)$.

Pengumpulan data dilakukan setelah responden diberi penjelasan sebelum persetujuan (PSP) dan pengisian lembar persetujuan menjadi responden. Penelitian ini telah memperoleh persetujuan dari komisi etik penelitian kesehatan Fakultas Kesehatan Masyarakat Universitas Airlangga pada tanggal 15 Desember 2016 dengan Nomor:648KEPK.

\section{HASIL \\ Karakteristik Responden}

Tabel 1 menunjukkan karakteristik responden meliputi umur dan tingkat pendidikan. Diperoleh sebagian besar umur perokok dan non perokok pada pegawai laki-laki di Fakultas Kesehatan Masyarakat Universitas Airlangga Surabaya adalah umur $30-49$ tahun. Berdasarkan tingkat pendidikan dapat dilihat bahwa sebagian besar perokok menempuh pendidikan formal terakhir pada tingkat SMA/Sederajat sedangkan non perokok pada tingkat Perguruan Tinggi.

Tabel 1. Karakteristik Perokok dan Non Perokok pada Pegawai Laki-laki di Fakultas Kesehatan Masyarakat Universitas Airlangga Surabaya

\begin{tabular}{|c|c|c|c|c|}
\hline \multirow{2}{*}{ Umur (tahun) } & \multicolumn{2}{|c|}{ Non Perokok } & \multicolumn{2}{|c|}{ Perokok } \\
\hline & Jumlah & Persen & Jumlah & Persen \\
\hline $19-29$ & 1 & 7,7 & 2 & 15,4 \\
\hline $30-49$ & 10 & 76,9 & 9 & 69,2 \\
\hline $50-64$ & 2 & 15,4 & 1 & 7,7 \\
\hline $65-80$ & 0 & 0,0 & 1 & 7,7 \\
\hline Total & 13 & 100,0 & 13 & 100,0 \\
\hline \multicolumn{5}{|c|}{ Tingkat Pendidikan } \\
\hline SMA/Sederajat & 6 & 46,2 & 11 & 84,6 \\
\hline Perguruan Tinggi & 7 & 53,8 & 2 & 15,4 \\
\hline Total & 13 & 100,0 & 13 & 100,0 \\
\hline
\end{tabular}


Tabel 2. Kebiasaan Merokok Perokok pada Pegawai Laki-laki di Fakultas Kesehatan Masyarakat Universitas Airlangga Surabaya

\begin{tabular}{lcc}
\hline \multicolumn{1}{c}{ Kebiasaan Merokok } & Jumlah & Persen \\
\hline Jumlah batang rokok yang dihisap per hari & & \\
$<10$ & 5 & 38,5 \\
$10-20$ & 7 & 53,8 \\
$\quad 120$ & 1 & 7,7 \\
\hline Total & 13 & 100,0 \\
\hline Lama merokok & 4 & \\
$\quad 5-10$ tahun & 9 & 30,8 \\
$\quad$ Lebih dari 10 tahun & 13 & 69,2 \\
\hline Total & & 100,0 \\
\hline Kategori menurut Indeks Brinkman & 5 & 38,5 \\
$\quad$ Perokok ringan & 6 & 46,1 \\
$\quad$ Perokok sedang & 2 & 15,4 \\
$\quad$ Perokok berat & 13 & 100,0 \\
\hline Total
\end{tabular}

Tabel 3. Tingkat Konsumsi Zat Gizi Perokok dan Non Perokok pada Pegawai Laki-laki di Fakultas Kesehatan Masyarakat Universitas Airlangga Surabaya

\begin{tabular}{lcccc}
\hline \multirow{2}{*}{ Zat Gizi } & \multicolumn{2}{c}{ Non Perokok } & \multicolumn{2}{c}{ Perokok } \\
\cline { 2 - 5 } & Jumlah & Persen & Jumlah & Persen \\
\hline Energi & 2 & & & \\
$\quad$ Cukup & 11 & 15,4 & 1 & 7,7 \\
$\quad$ Tidak Cukup & 13 & 100,0 & 13 & 100,0 \\
\hline Total & & & & \\
\hline Karbohidrat & 0 & 00,0 & 0 & 00,0 \\
$\quad$ Cukup & 13 & 100,0 & 13 & 100,0 \\
$\quad$ Tidak Cukup & 13 & 100,0 & 13 & 100,0 \\
\hline Total & & & & \\
\hline Protein & 11 & 84,6 & 7 & 53,8 \\
$\quad$ Cukup & 2 & 15,4 & 6 & 46,2 \\
$\quad$ Tidak Cukup & 13 & 100,0 & 13 & 100,0 \\
\hline Total & & & & \\
\hline Lemak & 9 & 69,2 & 9 & 69,2 \\
$\quad$ Cukup & 4 & 30,8 & 4 & 30,8 \\
$\quad$ Tidak Cukup & 13 & 100,0 & 13 & 100,0 \\
\hline Total & & & & \\
\hline a. Serat & 0 & 00,0 & 0 & 00,0 \\
$\quad$ Cukup & 13 & 100,0 & 13 & 100,0 \\
$\quad$ Tidak Cukup & 13 & 100,0 & 13 & 100,0 \\
\hline Total & & & & \\
\hline b. Kolesterol & 7 & 53,8 & 12 & 92,3 \\
$\quad$ Baik & 6 & 46,2 & 1 & 7,7 \\
\hline Lebih & 13 & 100,0 & 13 & 100,0 \\
\hline Total & & & &
\end{tabular}


Tabel 4. Perbedaan Konsumsi Zat Gizi Perokok dan Non Perokok pada Pegawai Laki-laki di Fakultas Kesehatan Masyarakat Universitas Airlangga Surabaya

\begin{tabular}{|c|c|c|c|c|c|}
\hline \multirow{2}{*}{ Zat Gizi } & \multicolumn{2}{|c|}{$\begin{array}{c}\text { Non Perokok } \\
(n=13)\end{array}$} & \multicolumn{2}{|c|}{$\begin{array}{c}\text { Perokok } \\
(\mathrm{n}=13)\end{array}$} & \multirow{2}{*}{$p$} \\
\hline & Mean & $\begin{array}{l}\text { Standar } \\
\text { Deviasi }\end{array}$ & Mean & $\begin{array}{l}\text { Standar } \\
\text { Deviasi }\end{array}$ & \\
\hline Energi (kkal) & $1.428,45$ & 293,38 & $1.380,95$ & 222,19 & 0,646 \\
\hline Karbohidrat (g) & 169,84 & 53,52 & 171,58 & 29,28 & 0,920 \\
\hline Protein $(\mathrm{g})$ & 58,41 & 11,06 & 49,19 & 17,06 & 0,115 \\
\hline Lemak (g) & 58,36 & 18,87 & 56,33 & 19,66 & 0,790 \\
\hline Kolesterol (mg) & 285,75 & 131,15 & 155,29 & 131,15 & 0,005 \\
\hline Serat (g) & 7,71 & 2,91 & 6,45 & 1,55 & 0,178 \\
\hline
\end{tabular}

Tabel 5. Kadar Kolesterol Darah Perokok dan Non Perokok pada Pegawai Laki-laki di Fakultas Kesehatan Masyarakat Universitas Airlangga Surabaya

\begin{tabular}{lcccc}
\hline \multirow{2}{*}{ Kadar Kolesterol Darah $(\mathbf{m g} / \mathbf{d L})$} & \multicolumn{2}{c}{ Non Perokok } & \multicolumn{2}{c}{ Perokok } \\
\cline { 2 - 5 } & Jumlah & Persen & Jumlah & Persen \\
\hline Normal & 11 & 84,6 & 10 & 76,9 \\
Tinggi & 2 & 15,4 & 3 & 23,1 \\
\hline Total & 13 & 100,0 & 13 & 100,0 \\
\hline
\end{tabular}

Tabel 6. Perbedaan Kadar Kolesterol Darah Perokok dan Non Perokok pada Pegawai Lakilaki di Fakultas Kesehatan Masyarakat Universitas Airlangga Surabaya

\begin{tabular}{|c|c|c|c|}
\hline Kadar Kolesterol Darah (mg/dL) & $\begin{array}{c}\text { Non Perokok } \\
(n=13)\end{array}$ & $\begin{array}{c}\text { Perokok } \\
(n=13)\end{array}$ & $p$ \\
\hline Mean & 174,64 & 173,11 & \multirow{2}{*}{0,916} \\
\hline Standar Deviasi & 34,669 & 38,281 & \\
\hline
\end{tabular}

\section{Kebiasaan Merokok Perokok}

Tabel 2 di atas menunjukkan bahwa berdasarkan Indeks Brinkman, perokok pada pegawai laki-laki di Fakultas Kesehatan Masyarakat Universitas Airlangga Surabaya paling banyak merupakan perokok sedang. Diperoleh sebagian besar perokok menghisap rokok sebanyak 10 - 20 batang dalam sehari dan telah merokok selama lebih dari 10 tahun.

\section{Tingkat Konsumsi Zat Gizi}

Tingkat konsumsi zat gizi energi, karbohidrat, protein, lemak, dan serat dikategorikan menjadi cukup dan tidak cukup. Sedangkan zat gizi kolesterol dikategorikan menjadi baik dan lebih. Tabel 3 di atas menunjukkan tingkat konsumsi zat gizi perokok dan non perokok pada pegawai laki-laki di Fakultas Kesehatan Masyarakat Universitas
Airlangga. Menurut tingkat konsumsi energi dan protein, responden non perokok yang tergolong cukup lebih banyak daripada responden perokok. Menurut tingkat konsumsi karbohidrat dan serat, seluruh responden baik non perokok maupun perokok tergolong tidak cukup. Menurut tingkat konsumsi lemak, sebagian besar responden baik non perokok maupun perokok tergolong cukup. Menurut tingkat konsumsi kolesterol, responden non perokok yang tergolong baik lebih sedikit daripada responden perokok.

\section{Perbedaan Tingkat Konsumsi Zat Gizi}

Tabel 4 di atas menunjukkan bahwa perokok memiliki rata-rata konsumsi energi, protein, lemak, kolesterol dan serat lebih rendah daripada non perokok. Namun responden perokok memiliki rata-rata konsumsi karbohidrat lebih tinggi daripada responden bukan perokok. Berdasarkan uji 
statistik menggunakan Independent t-Test didapatkan nilai $p$ untuk kolesterol lebih kecil dari $\alpha(0,05)$ yaitu sebesar 0,005 sedangkan nilai $p$ untuk energi, karbohidrat, protein, lemak dan serat lebih besar dari $\alpha(0,05)$. Artinya tidak terdapat perbedaan tingkat konsumsi zat gizi kecuali kolesterol antara perokok dan non perokok pada pegawai laki-laki di Fakultas Kesehatan Masyarakat Universitas Airlangga Surabaya.

\section{Kadar Kolesterol Darah}

Kadar kolesterol darah dikategorikan menjadi normal dan tinggi. Tabel $5 \mathrm{di}$ atas menunjukkan bahwa perokok yang memiliki kadar kolesterol darah dengan kategori tinggi lebih banyak daripada non perokok pada pegawai lakilaki di Fakultas Kesehatan Masyarakat Universitas Airlangga Surabaya.

\section{Perbedaan Kadar Kolesterol Darah}

Tabel 6 di atas menunjukkan bahwa rata-rata kadar kolesterol darah perokok lebih rendah daripada non perokok. Berdasarkan uji statistik menggunakan Independent $t$-Test didapatkan nilai $p$ sebesar 0,916. Artinya tidak terdapat perbedaan kadar kolesterol darah antara perokok dan non perokok pada pegawai laki-laki di Fakultas Kesehatan Masyarakat Universitas Airlangga Surabaya.

\section{PEMBAHASAN}

Hasil penelitian ini menunjukkan bahwa hanya konsumsi kolesterol yang memiliki signifikansi $p=0,005<\alpha(0,05)$. Konsumsi energi memiliki signifikansi $p=$ 0,646, karbohidrat memiliki signifikansi $p$ $=0,920$, protein memiliki signifikansi $p=$ 0,115 , lemak memiliki signifikansi $p=$ 0,790 , dan serat memiliki signifikansi $p=$ 0,178 . Artinya, hanya terdapat perbedaan konsumsi kolesterol antara responden perokok dan non perokok pada pegawai laki-laki di Fakultas Kesehatan Masyarakat Universitas Airlangga Surabaya sedangkan konsumsi zat gizi lainnya tidak terdapat perbedaan.

Menurut Healey (2011), paparan nikotin yang masuk tubuh seorang perokok dapat bereaksi dengan cepat melalui mulut kemudian larut dalam air ludah. Lalu nikotin masuk dalam pembuluh darah hingga terbawa ke otak. Nikotin akan diterima oleh reseptor asetilkolin-nikotinik untuk memicu sistem dopaminergik pada jalur imbalan yang dapat mengurangi selera makan. Merokok membuat makanan kurang bercita rasa bagi beberapa perokok sehingga memicu perokok untuk mengurangi porsi makan (Ilfandari, 2015).

Berdasarkan uji statistik pada penelitian ini diketahui bahwa tidak terdapat perbedaan tingkat konsumsi zat gizi kecuali kolesterol antara perokok dan non perokok pada pegawai laki-laki di Fakultas Kesehatan Masyarakat Universitas Airlangga Surabaya. Namun hasil pengolahan data konsumsi menunjukkan bahwa responden perokok memiliki rata-rata konsumsi energi, protein, lemak, kolesterol dan serat lebih rendah daripada responden non perokok. Hal tersebut sejalan dengan penelitian Cavallo et al dalam Aginta (2011) yang menyatakan bahwa perokok secara signifikan lebih mungkin untuk terlibat dalam pembatasan diet yang tidak sehat daripada non perokok.

$\begin{array}{ccc}\text { Menurut } & \text { hasil } & \text { wawancara } \\ \text { menggunakan } & \text { kuesioner } & \text { penilaian }\end{array}$
konsumsi pangan food recall 2x24 jam yang meliputi jenis dan jumlah makanan yang dikonsumsi, responden perokok cenderung memiliki jenis dan jumlah makanan yang lebih sedikit daripada responden non perokok. Rata-rata konsumsi energi responden perokok lebih rendah sebesar 47,5 kkal dari responden non perokok. Rata-rata konsumsi protein responden perokok lebih rendah sebesar 9,22 gram dari responden non perokok. Rata-rata konsumsi lemak responden perokok lebih rendah sebesar 2,03 gram dari responden non perokok. Rata-rata konsumsi kolesterol responden perokok 
lebih rendah sebesar 130,46 mg dari responden non perokok. Rata-rata konsumsi serat responden perokok lebih rendah sebesar 1,26 gram dari responden non perokok. Tetapi responden perokok memiliki rata-rata konsumsi karbohidrat lebih tinggi daripada responden non perokok. Rata-rata konsumsi karbohidrat responden perokok lebih tinggi sebesar 1,74 gram dari responden non perokok.

Selisih rata-rata konsumsi zat gizi antara responden perokok dan non perokok tidak terlalu jauh. Selisih rata-rata konsumsi zat gizi paling besar ditemukan pada kolesterol. Rata-rata konsumsi kolesterol responden perokok adalah 155,29 mg sedangkan responden non perokok adalah $285,75 \mathrm{mg}$. Sehingga ditemukan perbedaan tingkat konsumsi kolesterol yang signifikan antara responden perokok dan non perokok.

Menurut Arisman (2009), kebiasaan makan seseorang dapat dipengaruhi berbagai hal lain selain perilaku merokok. Kebiasaan makan dapat berasal dari kebiasaan yang dilakukan oleh anggota keluarga. Kebiasaan tersebut mempengaruhi pola frekuensi makan seseorang yang akan berdampak terhadap asupan zat gizinya. Selain itu, pola atau frekuensi makan juga dipengaruhi oleh ketersediaan pangan, keadaan ekonomi dan kepercayaan pribadi seseorang terhadap makanan. Kebiasaan makan seseorang juga dapat dipengaruhi oleh fisiologi makan. Hipotalamus adalah pusat pengendali selera makan terbesar. Sepasang nucleus lateralis dalam hipotalamus berperan sebagai pusat lapar dan nucleus ventromedial dalam hipotalamus berperan sebagai pusat kenyang. Jika terjadi kerusakan pada kedua nucleus ini maka dapat mempengaruhi asupan makan seseorang (Guyton dan Hall, 2006). Namun pada penelitian ini faktor tersebut tidak diidentifikasi. Hal tersebut menjadi keterbatasan penelitian ini. Untuk variabel kadar kolesterol darah, hasil penelitian ini menunjukkan bahwa kadar kolesterol darah memiliki signifikansi $p=0,916$ lebih dari $\alpha$ $(0,05)$. Artinya, tidak terdapat perbedaan kadar kolesterol darah antara responden perokok dan bukan perokok.

Menurut Mustikaningrum (2010), nikotin merupakan bahan kimia yang paling banyak di dalam rokok. Metabolisme nikotin dalam tubuh perokok sangat kompleks. Nikotin tersebar dengan cepat dalam darah dan hati. Nikotin dipecah menjadi kotinin yang memiliki waktu paruh lebih lama. Nikotin memiliki waktu paruh sekitar 2 jam, sedangkan kotinin memiliki waktu paruh sekitar 48 jam. Kotinin dapat meningkatkan sekresi adrenalin pada korteks adrenal yang mendorong peningkatan konsentrasi serum asam lemak bebas yang selanjutnya menstimulasi sintesis dan sekresi kolesterol hepar ke dalam sirkulasi darah sehingga meningkatkan kadar kolesterol darah.

Menurut penelitian Kusumasari (2015) pada pegawai salah satu pabrik gula menunjukkan bahwa responden yang merokok dan mempunyai kadar kolesterol tinggi sebanyak 26 responden sedangkan responden yang merokok dan mempunyai kadar kolesterol normal sebanyak 4 responden. Dari kelompok kontrol didapatkan responden yang tidak merokok dan mempunyai kadar kolesterol normal sebanyak 27 responden sedangkan responden yang tidak merokok dan mempunyai kadar kolesterol tinggi sebanyak 3 responden.

Penelitian Kusumasari

menunjukkan bahwa rata-rata kadar kolesterol total responden yang merokok adalah 250,5 $\mathrm{mg} / \mathrm{dL}$, sedangkan rata-rata kadar kolesterol responden yang tidak merokok adalah 166,2 mg/dL. Didapatkan perbedaan kadar kolesterol total yang signifikan antara responden yang merokok dan responden yang tidak merokok. Sedangkan hasil penelitian ini menunjukkan bahwa rata-rata kadar kolesterol darah responden perokok adalah 173,11 $\mathrm{mg} / \mathrm{dL}$ sedangkan rata-rata responden non perokok adalah $174,64 \mathrm{mg} / \mathrm{dL}$. Selisih rata-rata kadar kolesterol darah tidak terlalu jauh, yaitu 1,53 $\mathrm{mg} / \mathrm{dL}$.

Hasil pemeriksaan kadar kolesterol darah menunjukkan bahwa responden perokok yang memiliki kadar kolesterol darah dengan kategori tinggi adalah sebesar 23,1\% sedangkan responden bukan perokok adalah sebesar 15,4\%. Artinya, jumlah responden yang memiliki kadar kolesterol darah dengan kategori tinggi lebih banyak ditemukan pada perokok daripada responden non perokok. Responden perokok pada penelitian ini yang tergolong perokok ringan sebesar $38,5 \%$, perokok sedang sebesar $46,1 \%$ dan perokok berat hanya sebesar $15,4 \%$. Hasil penelitian Trivedi, et al. (2013) menyatakan bahwa kadar koleterol total lebih tinggi pada perokok dibandingkan dengan non perokok. Peningkatan yang signifikan ditemukan pada 
perokok berat. Berdasarkan analisis mengenai durasi dan intensitas dari merokok, peningkatan kolesterol serum yang signifikan berhubungan dengan durasi dan intensitas dari merokok. Semakin banyak jumlah rokok yang dihisap semakin tinggi juga kadar kolesterol total pada responden (Devaranavadgi et al., 2012 dalam Kusumasari, 2012).

Hasil penelitian Sulviana (2008) didapatkan sebanyak 15 responden mempunyai kebiasaan merokok dengan sebagian besar telah merokok selama lebih dari 15 tahun. Berdasarkan jumlah rokok yang dihisap, 8 responden tergolong perokok ringan, 3 responden tergolong perokok sedang dan 4 responden tergolong perokok berat. Seluruh responden merokok mempunyai kadar kolesterol total yang normal. Hasil penelitian tersebut menyimpulkan bahwa jumlah rokok yang dihisap berhubungan dengan kadar kolesterol total. Sedangkan responden perokok pada penelitian ini sebagian besar merupakan perokok sedang. Artinya, peningkatan kadar kolesterol darah yang signifikan pada perokok pada penilitian ini belum dapat ditemukan.

Hiperkolesterolemia adalah suatu keadaan kadar kolesterol darah melebihi batas nilai normal, yaitu kurang dari $200 \mathrm{mg} / \mathrm{dL}$ (National Heart, Lung and Blood Institute, 2005). Selain faktor merokok terdapat berbagai hal lain yang dapat mempengaruhi kadar kolesterol total seseorang. Kadar kolesterol darah dapat dipengaruhi oleh makanan di antaranya asupan kolesterol dan lemak yang tinggi.

Berdasarkan hasil penelitian dapat diketahui bahwa terdapat perbedaan tingkat konsumsi kolesterol antara responden perokok dan non perokok. Rata-rata konsumsi kolesterol responden perokok adalah 155,29 mg sedangkan responden non perokok adalah 285,75 mg. Rata-rata konsumsi kolesterol responden perokok lebih rendah sebesar $130,46 \mathrm{mg}$ dari responden non perokok. Mengonsumsi makanan yang mengandung kolesterol tinggi berisiko meningkatkan kadar kolesterol darah (Malik, et al., 2013). Jika banyak mengkonsumsi bahan makanan yang mengandung kolesterol tinggi, maka hati akan menghentikan pengambilan LDL karena hati mempunyai cukup kolesterol, sehingga meningkatkan kolesterol dalam darah (Ayuandira, 2012). Oleh karena itu, rata-rata kadar kolesterol darah pada responden non perokok lebih tinggi daripada rata-rata kadar kolesterol darah pada responden perokok. Namun selisih rata-rata kadar kolesterol darah antara responden perokok dan non perokok tidak terlalu jauh sehingga peningkatan kadar kolesterol darah yang signifikan pada perokok pada penilitian ini belum dapat ditemukan. Selain faktor makanan, faktor karakteristik individu seperti umur juga dapat mempengaruhi kadar kolesterol darah seseorang. Menurut National Institute of Health (2002), kategori umur yang berisiko lebih besar menderita hiperkolesterolemia adalah lebih dari 45 tahun. Semakin tua seseorang maka semakin berkurang kemampuan reseptor LDL-nya. LDL reseptor merupakan faktor penghambat sintesis kolesterol dalam tubuh. Semakin menurunnya aktivitas reseptor LDL akan menyebabkan sintesis kolesterol menjadi meningkat sehingga kadar total kolesterol tinggi. Kadar kolesterol darah manusia bervariasi dan meningkat sejalan dengan pertambahan umur (Mayes, 2000 dalam Ayuandira, 2012). Pada penelitian ini, rata-rata umur responden perokok adalah 41,69 tahun dan responden bukan perokok adalah 42,15 tahun. Artinya, umur responden perokok dan bukan perokok masih berada di bawah faktor risiko hiperkolesterolemia. Sehingga perbedaan yang signifikan kadar kolesterol darah antara perokok dan non perokok pada penelitian ini belum dapat ditemukan.

\section{SIMPULAN}

Berdasarkan hasil penelitian yang telah dilakukan dapat ditarik kesimpulan bahwa rata-rata konsumsi zat gizi dan kadar kolesterol darah antara responden perokok dan responden non perokok pada pegawai laki-laki di Fakultas Kesehatan Masyarakat Universitas Airlangga Surabaya tidak berbeda jauh. Rata-rata tingkat konsumsi kolesterol antara responden perokok dan responden non perokok memiliki selisih terbesar sehingga secara uji statistik memiliki perbedaan yang signifikan. Sedangkan ratarata kadar kolesterol darah antara responden perokok dan responden non perokok memiliki selisih kecil sehingga secara uji statistik tidak memiliki perbedaan yang signifikan. Namun pada penelitian ini jumlah responden yang memiliki kadar kolesterol darah dengan kategori tinggi lebih banyak ditemukan pada perokok daripada responden non perokok. 
Merokok memberikan dampak buruk bagi kesehatan sehingga diperlukan untuk mengurangi jumlah rokok yang dihisap atau bahkan menghindari merokok. Semakin lama terkena paparan rokok maka lebih mudah terkena penyakit akibat paparan rokok.

\section{DAFTAR PUSTAKA}

Aginta, E., 2011. Hubungan antara Merokok dan Kebiasaan Makan dengan Status Gizi pada Remaja Putra. Artikel Penelitian. Universitas Diponegoro.

Almatsier, S. 2009. Prinsip Dasar Ilmu Gizi. Jakarta: Gramedia Pustaka Utama.

Arisman. 2009. Gizi dalam Daur Kehidupan. Jakarta: EGC.

Ayuandira, A. 2012. Hubungan Pola Konsumsi Makan, Status Gizi, Stres Kerja dan Faktor Lain dengan Hiperkolesterolemia pada Karyawan PT Semen Padang Tahun 2012. Skripsi. Universitas Indonesia.

Balitbangkes, RI. 2010. Laporan Hasil Riset Kesehatan Dasar 2010. Indonesia.

Balitbangkes, RI. 2013. Laporan Hasil Riset Kesehatan Dasar 2013. Indonesia.

Departemen Kesehatan RI. 2007. Pedoman Pengendalian Penyakit Jantung dan Pembuluh Darah. Jakarta: Direktorat Pengendalian Penyakit Tidak Menular, Direktorat Jendral Pengendalian Penyakit dan Penyehatan Lingkungan.

Guyton, A.C., Hall, J.E. 2006. Textbook of Medical Physiology, 11th ed. Philadelphia, PA, USA: Elsevier Saunders.

Healey, J. 2011. Tobacco Smoking. Australia: Spinney Press.

Ilfandari, A. 2015. Hubungan Perilaku Merokok dengan Indeks Massa Tubuh Remaja Putra. E-Jurnal Obstetrika, 3(1): $1-15$.

Kusumasari, P. 2015. Hubungan antara Merokok dengan Kadar Kolesterol Total pada Pegawai Pabrik Gula Tasik Madu Karanganyar. Skripsi. Universitas Muhammadiyah Surakarta.

Larson, D.E. 2003. Mayo Clinic Family Health Book: The Ultimate Home Medical Reference. 3rd Ed. USA: Mayo Clinic.
Listiana, L. 2010. Kadar Kolesterol Total pada Usia $25-60$ Tahun. Jurnal Keperawatan Muhammadiyah, Volume 5 (1), pp. 36 - 40.

Malik, M.A., Mewo, Y.M., Kaligis, S.H.M. 2013. Gambaran Kadar Kolesterol Total Darah pada Mahasiswa Angkatan 2011 Fakultas Kedokteran Universitas Sam Ratulangi dengan Indeks Massa Tubuh 18,5-22,9 kg/m². Jurnal e-Biomedik (eBM), Volume 1(2), pp. 1008 - 1013. https://doi.org/10.35790/ebm.1.2.2013. 3310

Mustikaningrum, S. 2010. Perbedaan Kadar Trigliserida Darah pada Perokok dan Bukan Perokok. Skripsi. Universitas Sebelas Maret.

National Heart Lung and Blood Institute (NHLB). 2005. What Is Cholesterol?.

National Institute of Health. 2002. Third Report of National Cholesterol Education Program (NCEP) Expert Panel on Detection, Evaluation and Treatment of High Blood Cholesterol in Adults (Adults Treatment Panel III). NIH Publication. https://doi.org/10.1001/jama.285.19.24 86

Peraturan Menteri Kesehatan Republik Indonesia No. 75 Tahun 2013 Tentang Angka Kecukupan Gizi Yang Dianjurkan Bagi Bangsa Indonesia. Jakarta.

Sulviana, N. 2008. Analisis Hubungan Gaya Hidup dan Pola Makan dengan Kadar Lipid Darah dan Tekanan Darah pada Penderita Jantung Koroner. Skripsi. Institut Pertanian Bogor.

Trivedi, R.S., Anand, A.K., Jamnagar. 2013. Effect of Smoking on Lipid Profile. National Journal of Otorhinolaryngology and Head \& Neck Surgery. 1(10): 13 - 15.

WHO-FCTC. 2015. WHO Report on The Global Tobacco Epidemic 2015 Raising Taxes on Tobacco.

WikiBuku. 2015. Indeks Brinkman. 